\title{
Business Divestment in South Africa: In Who's Best Interest?
}

\author{
Paul Lansing \\ University of lowa
}

\section{Sarosh Kuruvilla \\ University of lowa}

\begin{abstract}
In recent years, there has been considerable pressure on corporations doing business in South Africa to divest and withdraw from that country. While this moral view espouses withdrawal, this article seeks to provide insight into the practical consequences of divestment. One of the questions addressed is how does foreign divestment affect Black South Africans, those who are supposed to benefit from a divestment policy.
\end{abstract}

\section{Introduction}

In June 1987, Rev. Leon Sullivan advocated a total change in policy and a plea for a complete corporate withdrawal from South Africa. As the widely respected architect of the Sullivan Principles, a code of fair employment tenets for United States companies in South Africa, his announcement implied a dramatic reversal of the policy he had advocated for the last decade. To understand the reasons for this dramatic reversal in policy, it is necessary to understand the history behind the principles itself.

More than a decade ago, when Rev. Leon Sullivan, pastor of the Zion Baptist Church in Philadelphia, was elected to the Board of Directors of General Motors, he shocked his fellow directors by proposing that GM should get out of South Africa. When he learned that it would be impractical for GM to close down its 4500 employee plant and abandon its employees (most of them non-White) to fend for themselves, he proposed that GM and other U.S. corporations operate under a stringent code of ethics. The Sullivan Principles, as they came to be known, emphasized non-segregation, equal employment practices, equal pay and working conditions, training for the advancement of Blacks and other non-Whites (Coloreds and Indians), and the improvement of the quality of life outside the work environment. Sullivan's call for a total withdrawal is an implicit acknowledgement that the principles have not accomplished what they were designed to accomplish, namely, provide Blacks and non-Whites with the economic and social strength to overthrow the apartheid system. His call for total withdrawal and the imposition of economic sanctions is now designed to bring economic pressure on the White South African Government to end apartheid. However, it is not clear that that will necessarily follow.

The U.S. involvement in South Africa has been one of the biggest U.S. foreign policy issues in the last three years. Public opinion and corporate action have been divided about the issue. There is a strong anti-apartheid lobby (particularly from student groups), that advocates the stand that it is morally wrong to remain in South Africa, since any involvement there is construed as indirectly supporting apartheid. This lobby has become increasingly strong in the last year. The Wall Street Journal noted that the issue of U.S. involvement in South Africa has eventually transcended politics and become a litmus test of moral correctness in U.S. public life. ${ }^{1}$ These antiapartheid activists criticize the Sullivan Principles as being ineffective in dismantling apartheid, and support the imposition of total economic sanctions, and divestment, i.e., a total U.S. withdrawal.

On the other hand, there is a considerable amount of pressure from U.S. corporations against a total withdrawal from South Africa. The corporations argue that a total withdrawal would weaken the position of companies that say that they can force change only by staying in South Africa. Many companies believe that U.S. involvement in South Africa has benefitted the Blacks substantially. For example, Ron Johnson of Kelloggs indicates that it is possible that Kelloggs could stay and help with a peaceful fundamental change 
and "we believe we can do that, provided we are able to run a successful business." There are many organizations that share Johnson's views. $^{2}$

Consequently, Americans seem to be divided on the issue of U.S. involvement in South Africa. The "moral" view espouses withdrawal, while the "practical" view espouses a continued U.S. presence in the region. This paper seeks to provide answers to the following questions. What has been the effect of the U.S. presence in South Africa on the socio-economic status of South African

Blacks? To what extent do sanctions, divestment and disinvestment have the potential to really bring about pressure on the White South African government to change its policy of apartheid? What are South African Blacks perceptions of the effect of sanctions and divestment? What happens to the businesses that U.S. companies abandon?

\section{Impact of foreign corporations on South African Blacks}

The 240 U.S. firms doing business at the end of 1986 in South Africa employ about 100000 Blacks, whose families total nearly a million people. In more absolute terms, however, direct employment of 100000 Blacks corresponds to only about $2 \%$ of the total population of South Africa.

All Sullivan signatory companies now pay Blacks and Whites equally for equal work and report full integration of work areas, restrooms, and recreational facilities. But it is in the areas of education, training and social justice that these corporations have made some larger impact. In 1985, Sullivan signatory companies averaged roughly $\$ 500$ per employee for education, training, health and welfare. In 1986, Sullivan Reports indicate that the amount spent by companies exceeded \$38 million in education, housing and social justice. This translates into roughly $\$ 842$ per Black/non-White employed in U.S. corporations, but only $\$ 1.50$ when calculated on a per capita basis for the country's total Black population.

Programs by these corporations include both assistance to their own employees, as well as assistance to the general Black population. "In house" assistance incorporates housing, health and education. Shell Corporation of South Africa, a subsidiary of the Royal Dutch Shell group based in the United Kingdom and the Netherlands, for example, provides housing to their employees at subsidized rents under \$5 monthly. They also maintain elementary schools for some 1500 Black children of employees at their Rietspruit coal mining site. General Motors has spent several million dollars in housing assistance, and until education became free in 1987, GM paid for all books and tuition of all children of its Black employees. Other programs by both American and European corporations include free medical assistance, housing loans for its employees and other welfare activities.

While these programs have a limited impact, since they are employee directed, programs to aid the general Black population have been considerable. In the field of education alone, where arguably their impact has been the greatest, in 1986 a total of \$17 million was spent in education of non-Whites not employed by diese corporations. IBM has instituted a \$10 million "writing to read program" in 250 schools to assist 37000 upper elementary black children to make the transition from education in Zulu, Ndebele, Xhosa, Swazi, Sutho, Venda, Lemba, and other African languages to English.

Other corporations have joined the adopt a school program by which 332 deteriorating Black schools have been refurbished and supplied with library and learning aids. The University of Capetown and the University of the Witwatersrand, once virtually all White, now support some 500 Black students each, largely funded by scholarships established by foreign corporations. Upjohn Pharmaceuticals, for example, a manufacturer of medicines and agricultural projects, provides medical textbooks to Black colleges, and provides financial support to students in the fields of nursing, pharmacy, medicine, and agricultural technology. The U.S. State Department reports that $\$ 160$ million has been spent on education alone in the last 8 years by these corporations. ${ }^{3}$

In the field of training, 3380 non-White private businesses were assisted in 1985 alone, with about \$10 million in U.S. corporate 
funds. Possibly the most dramatic single instance of training was Fluor Corporation's massive project in which more than 20000 welders were trained on one site. As a result, many of these welders were able to set up welding and related businesses in their homelands and villages. Black entrepreneurship has increased about 700\% since 1978, the first reporting year after the Sullivan Principles were adopted.

In other spheres, also, contributions have been made. The NCR Corporation has donated \$2 million to the Urban Foundation to help fund various Black projects, including lobbying, research, self-help housing, adult education, and business development IBM, although sold to a South African organization, is still expanding its small builders loan scheme to Black towns. Michael Levin, Economist and Director of the Port Elizabeth Campus of the predominantly Black Vista University, indicates that foreign companies operating in the Eastern Cape province contributed $25 \%$ of the gross regional product in 1984 . In addition, these organizations provided about $84 \%$ of the social welfare funds spent outside government budgets that year. ${ }^{4}$

However, it still must be borne in mind that all these activities constitute a net total of only $\$ 1.50$ per capital investment, of the total Black population. But at least that much is being done. As William D. Broderick of Ford Motor Company noted, "The principles have clearly fallen short of the ideal, but the record is pretty impressive still." ${ }^{5}$ But it is clear that the sphere of social responsibility of these corporations, whether voluntary or induced, have had some small impact. It is feared that disinvestment will terminate many of these social responsibility projects.

There is a perception in the minds of many Americans that it is only U.S. companies that are disinvesting in South Africa, while European organizations have not been as quick as U.S. corporations to divest However, latest reports indicate that there' is mounting pressure in Europe for disengagement. The impact of a European withdrawal from South Africa will be much greater than a U.S. pull out. Out of the 400 000 Blacks employed in foreign corporations, some 350000 work for European owned corporations. GM, employing about 4000 workers, is arguably the largest U.S. employer, although there are at least 20 European employers who each employ more. (See Tables I and II.) The British have the largest involvement in terms of total workers employed.
TABLE I

Employment in large foreign owned corporations

\begin{tabular}{lll}
\hline Organization & Nationality & $\begin{array}{l}\text { Number of } \\
\text { employees }\end{array}$ \\
\hline Consolidated Gold Fields & (B) & 93851 \\
Imperial Chemical Industries & (B) & 27000 \\
Standard Chartered & (B) & 22848 \\
Lonrho & (B) & 10817 \\
Courtaulds & (B) & 8198 \\
Royal Dutch/Shell Group & (B/N) & 8160 \\
Pilkington Brothers & (B) & 8016 \\
Unilever & (B/N) & 7372 \\
British Electric Traction & (B) & 7238 \\
BTR & (B) & 6482 \\
Volkswagen & (G) & 6000 \\
Siemens & (G) & 5700 \\
BOC & (B) & 5666 \\
Daimler Benz & (G) & 5000 \\
British Petroleum & (B) & 4880 \\
General Electric (B) & (B) & 4677 \\
Holderbank Financier & (S) & 4500 \\
Rio Intro-Zinc & (B) & 4310 \\
BAT & (B) & 4139 \\
Nestle & (S) & 4000 \\
\hline
\end{tabular}

Note: B - British, N - Netherlands, G - West Germany, S- Swiss.

Source: Wall Street Journal, December 3, 1986, p. 26.

TABLE II

Employment in large U.S. corporations

Corporation

Number of employees

Coca Cola

4800

Ford Motors

4600

GM

4000

Mobil

3300

USG

2600

Goodyear

2600

Caltex Petroleum

2200

Allegheny International

2000

IBM 1900

General Electric

850

Dressen Industries

800

Xerox

Source: Wall Street Journal, Dec. 3, 1986, p. 26. 
European governments have codes similar to the Sullivan Principles, as do other nations. The European Community Code, the Canadian, Japanese and Australian codes, are all as stringent as the Sullivan Principles. But it appears that European governments are still debating whether a total withdrawal is in the interest of the Black community or not

\section{Sanctions, divestment and disinvestment}

When talking about sanctions, it is necessary first to understand the meaning of the terms that are used before we can clearly evaluate their impact. In practical terms, "sanctions" refer to government trade and investment restrictions against South Africa. Broadly, it includes stoppage of various governmental sales or purchases to and from the country. However, in the context of the current situation in South Africa, the term sanctions appears to be broadly used to include both divestment and disinvestment Journals, in fact, tend to use these terms interchangeably when evaluating their impact.

"Divestment" refers to the sale of ownership rights through the sale of stocks/bonds, in corporations in South Africa, by individuals, cities, schools, states, governments and other institutions.

"Disinvestment" refers to the outright sale of foreign owned businesses in South Africa. The sale could be to local businessmen, either Black or White, to employees, or to other larger corporations. While some organizations have been sold, .others, like Eastman Kodak, have just stopped their operations in South Africa totally. Hereafter, in the evaluation of the impact of these activities on South Africa, the term sanctions shall include divestment and disinvestment activity.

The United States has been the most active in divestment activity, much of it due to public pressure. By early 1987 , about 21 states in the U.S. had adopted divestment policies (see Table III). Joining the list of 21 states, 68 U.S. cities have also opted to divest, 55 of which have elected to do so within the last two years. Some of the larger cities include Atlanta, Boston, Baltimore, Cincinnati, Los Angeles, Miami, Minneapolis, New Orleans, New York, Oakland, Philadelphia, Pittsburgh, San Francisco, Washington D.C. Ten highly populated state counties have also divested. A total of 100 educational institutions have divested \$410 893546 in funds, with Harvard

TABLE III

States adopting divestment policies by early 1987

\begin{tabular}{lll}
\hline $\begin{array}{ll}\text { Colorado* } \\
\text { Connecticut }\end{array}$ & $\begin{array}{l}\text { Maryland } \\
\text { Massachusetts }\end{array}$ & $\begin{array}{l}\text { North Dakota* } \\
\text { Oklahoma }\end{array}$ \\
Florida & Michigan & Rhode Island \\
Iowa & Minnesota* & Vermont \\
Kansas* & Nebraska & Virgin Islands \\
Louisiana & New Jersey & West Virginia \\
Maine* & New Mexico* & \\
\hline
\end{tabular}

- Policies adopted by Administrative Action.

Source: David Romano, 'American Business: The Divestment Rush', Family Protection Scoreboard, 1987 Edition on South Africa.

University divesting $\$ 54800$ 000, University of Michigan $\$ 51000000$, Columbia University $\$ 41700000$, University of Minnesota $\$ 18191$ 763. Many other organizations have also divested funds of corporations doing business with South Africa. Since 1984 , about 40 foreign corporations have divested, with about 50 in 1986. In 1987, 18 foreign corporations have already divested or disinvested, while 15 are in the process of doing so. Yet, about 200 American corporations are still doing business in South Africa. ${ }^{6}$ 


\section{Sanction activities undertaken by various governments}

On the basis of conclusion No. 4 of the 1985 Report of the Committee on Apartheid by the ILO, ${ }^{7} 16$ points were identified as corresponding to sanctions against South Africa. These range from extension of arms embargo to include sales by South African subsidiaries of transnational corporations, prohibition of military sales to South Africa, stopping of all investment guarantees, export credits and trade promotion measures, stopping new investment in South Africa, prohibiting and restricting oil supplies through bans on ships and tankers to South Africa, banning the sale of Krugerrands, all out bans on purchases from South Africa, and the stopping of all sports and cultural contacts with South Africa. By the end of 1986, 92 governments had reported some action on the lines of the 16 principles, but not one government could conclusively state that it had observed all principles to the utmost extent All governments surveyed had indicated varying responses to the principles listed above, and had made varying progress in the spheres of investment trade and economic relations, support for neighboring states, and support for national liberation movements.

There are differences of opinion, amongst industrialists and corporations, on the wisdom or the intended effects of sanctions. Within the U.S., opinion on this is clearly divided, although mounting public pressure has moved in the direction of sanctions and divestment. For example, while Walter Fauntroy, District of Columbia delegate to the U.S. Congress, strongly supports disinvestment, Herman Nickel, U.S. Ambassador to South Africa from 1982 until October 1986, wants U.S. corporations to remain involved there. A Gallup Poll survey in September, 1985 indicated that 44\% of American citizens voted for impartiality, while 8\% press for general sanctions, $5 \%$ for trade embargoes.

Of late, other European nations have indicated a desire or movement in this direction. In Europe, until recently, most organizations have taken the view against divestment, although it is not clear that the prime motive for this has been helping with the political emancipation of the Blacks. However, even those organizations are facing pressure to divest. A change in the mood of European companies is reflected by the decision of Barclay Bank (United Kingdom) to divest The reaction in the European Community to Barclay's withdrawal has been mixed. Some support Barclay's actions, stating that "staying is no longer essential to their concept of social responsibility". ${ }^{8}$ But European companies are more inclined to be "stayers", while the Americans are the "quitters". However, there is a subtle trend beginning in Britian, South Africa's largest foreign investor, toward quiet disengagement. Several smaller British organizations have already sold out entirely. For example, Smiths Industries PLC, Valor PLC, Crown House PLC, and some of the bigger organizations have already divested their stake in South Africa. Prudential Corporation of Britian swapped its majority in a South African branch last fall with Liberty Life Association of South Africa. British Electric Traction Co. has pared its freight and bus businesses, while Metal Box PLC has gradually reduced its holdings to only $25 \%$ of Metal Box South Africa. Many of these actions have ostensibly been to improve the company's image on the stock market. The banks have also followed this lead. Standard Chartered, now the biggest foreign bank in the country, shrunk its holding from $53 \%$ to under $40 \%$, while Hill Samuel and Co., which put together more South African loans than any other company in 1985, expects to own only $13 \%$ of its South African subsidiary by the end of this year. ${ }^{9}$

In September 1986, the European Common Market imposed a more stringent set of actions/ sanctions that may act as a further restraint on European organizations, although those sanctions may not be as stringent as the sanctions passed by the U.S. Congress over President Reagan's veto. Yet, it is only a few European organizations that feel the compulsion to quit South Africa, unlike the norm in the U.S. An additional disincentive to quit is the fact that unlike the Americans, Europeans can't retreat into large home markets. ${ }^{10}$ West German companies appear to be eager to fill the void left once the Americans withdraw. Daimler-Benz decided last year to spend an additional $\$ 75$ million in its South African plant. Over the last three years Volkswagen has increased its financial contribution in its subsidiary by $\$ 200$ million. Sir Leslie Smith, who chairs the British Industry Committee on South Africa, pleaded against sanctions, saying that they were difficult to enforce, that they could damage the South African economy, add to political problems, and lower the standard of living of the population. ${ }^{11}$ 
Instances of withdrawal from other nations are rarer. An Australian company, Colonial Mutual Life Assurance Corporation, announced on January 9, 1987 its decision to disinvest. On March 16, 1987, Norway's parliament approved an extensive trade ban against South Africa. The unilateral boycott, proposed in 1986, gives domestic organizations until September 1987 to cut remaining trade ties with South Africa. Sweden has also advocated a trade ban, and Swedish companies have till October 1987 to end trade with South Africa. Switzerland has had meetings with Roman Catholics and Protestants to hear church complaints about Swiss loans to South Africa. The reaction in the Netherlands appears to be mixed. The Netherlands Reformed Church, the largest Protestant body in the Netherlands, is split on whether to withdraw investments in South Africa as a gesture against apartheid. The Royal Dutch Shell group indicated on April 16, 1987, that it had no intention of divesting. The Israeli cabinet decided in March 1987 that it will not sign any new military contacts with South Africa. Previously, Israel had defended its military ties to South Africa, on the basis of domestic need, i.e., divestment would bring an end to Israel's arms industry and generate unemployment. After a meeting between Japanese Prime Minister Yasuhiro Nakasone and Oliver Tambo, leader of the African National Congress, in Tokyo on March 20, 1987, Japanese officials indicated that Japan does not favour comprehensive economic sanctions against South Africa. The spokesman said that the Japanese government believes that the people of South Africa would suffer, rather than the government if sanctions were imposed.

The point of the above discussion is that if this European trend of divestment continues, it will weigh more heavily on the South African government than a solely U.S. departure. A U.S. pullout is, at best, a limited effort that will have very little direct impact, although it's indirect effect in terms of publicity could be potentially greater. But the European pullout could have a larger impact, if we keep in mind that at least $60 \%$ of South Africa's foreign investment comes from Europe. In the early 1980s European banks lent more than a billion dollars in loans to South Africa. These organizations employ more than 350000 Black workers, out of an approximate total of 400000 Black workers employed by foreign corporations. Consequently, apart from having a detrimental effect on Black unemployment, a U.S. corporate departure would probably have very little potential to have a lasting impact on the political economy of South Africa.

\section{Effects of sanctions on Blacks}

What has been the real impact of sanctions on the Blacks in South Africa? Much of the evidence of the impact on Blacks cannot be expressed in quantitative terms. Consequently, we have to depend largely on mixed and anecdotal evidence. In addition, die fact that sanctions are detrimental to Blacks itself is a moot point since (hey are designed to be that way. The key question here is not whether sanctions are detrimental, but whether Blacks perceive a benefit from their imposition. In other words, does it hurt the Whites? Or, does it hurt the Blacks more?

First, it is clear that with sanctions and divestment, much of the social responsibility expenditures generated by Sullivan adherents will be curtailed. Schools will lack funds and without the support of U.S. and other companies, community health projects designed for the social and educational emancipation of Blacks in South Africa will come to a halt.

Second, divestment by definition implies a sale to a locally owned company. The question here is whether locally owned organizations will continue the social overhead costs hitherto pledged by foreign organizations. The answer, at best, seems to be that they will not. There is evidence to indicate that when local organizations take control of companies sold by foreign corporations, they do not necessarily adhere to the Sullivan Principles. Lionel Grewan, Executive Director of the Sullivan Signatory Association, notes that the history of divestment is that as soon as a company becomes wholly South African owned, it tends to cut its links with the Sullivan Principles. More organizations have been sold to White South African groups rather than Black South Africans. Divestment, when it is divestment to Black political-economic empowerment would be good, but when it is to White South Africans, then it loses much of the meaning and intention of economic sanctions against South Africa. A report by Eric Wiggin indicates that observers will terminate 
their Sullivan social responsibility projects for education, community improvement and social justice. ${ }^{12}$

One notable exception to selling organizations to White South Africans is the proposed example of Ford Motor Company, where the automaker is holding discussions with labor and community leaders regarding its 62\% stake in Samcor (South African Motor Corporation), the giant South African conglomerate. Ford is basically seeking an alternative to a complete pull out, which will harm the employees, $70 \%$ of whom are Black Ford is seriously exploring the question of whether its stake can be turned over to its employees. At the annual general meeting, Chairman Donald Peterson pointed out that total withdrawal would result in the closure of Samcor and the loss of 16000 related jobs. The shareholders of Ford voted against total withdrawal. The logical solution, according to Ford officials, appears to be to transfer its holdings to Samcor employees. Labor and community leaders are still debating the idea. There is much cause for concern from unions on this issue. The union is concerned that once Ford loosens its ties, Samcor may have difficulty competing in South Africa's overcrowded auto industry. It also questions whether the company would pay sufficient dividends to make the share holdings worthwhile. Instead, the union prefers longer term compensation and assurances that pensions will still be honored.

The auto workers, a part of the National Union of Metalworkers, are understandably sensitive to disinvestment moves. In 1985, when Ford shutdown its operations in Port Elizabeth, several thousand workers went jobless. When GM disinvested in October 1986 about 2000 autoworkers went on strike, demanding compensation in case the company, sold to local owners, went under. It will be interesting to see how the labor and community leaders react to Ford's offer, since the potential benefits of selling to workers is much better than selling to local, White owned South African firms, especially in the context to a lack of available Black entrepreneurship to take over and make Samcor a totally Black owned organization.

However, most American firms have sold their holdings to local White controlled firms. Buyers include giant conglomerates like Premier Corporation, which purchased Dow Chemical Company's subsidiary, and smaller firms like Northern Engineering, which acquired Eaton's operations. Other U.S. divisions have been sold to White South Africans who managed the subsidiary, or to foreign firms. Only a handful of organizations, including Eastman Kodak, have completely shut down their operations. Companies that have been sold to Blacks are a rare phenomenon. Coca Cola, was the first American firm to do so. In March 1985, $85 \%$ of its wholesalers and retailers, $60 \%$ of whom are non-White, bought $1 / 3$ of Coke's South African subsidiary. Ford's proposed sell off is the only other case.

However, when American companies sell their subsidiaries, they often arrange to supply their parts or products to the new owners. According to the Massachusetts based Mitchell Investment Management, 35\% of the 106 U.S. subsidiaries sold in the last two years continue to sell their goods, through licensing, distribution, franchising or trademark agreements. ${ }^{13}$ According to a spokesman of Mitchell Investment, firms still manage to make a profit, without the expenses of direct involvement, and consequently, many of the companies that said they were pulling out really were not.

The primary effects of divestment/disinvestment on Blacks is reflected in a loss of jobs. U.S. divestitures have caused scattered layoffs. Black joblessness, estimatedly increased by 300000 over the last three years from 3 million. Figures on estimates of employment and unemployment are at best, random estimates, many of them not believable. Figures obtained from the government of South Africa are suspect. If these sanctions are really hurting the South African economy, the South African government is liable to overstate the effect of sanctions on Blacks, in an effort to draw the heat away from the divestment movement The Washington Times reports that Black unemployment is estimated at about 2 million, or about $30 \%$ of the Black labor force. ${ }^{14}$ The number of unemployed Blacks and Coloreds, has jumped to 81 000, from 31000 in eight months. The U.S. ban on the importation of South African rock lobsters, is crippling the lobster fishing industry in the Cape Province, and could throw about 70000 Black fishermen out of jobs.

A study published by the Trade Policy Research Centre in London estimates that broad economic sanctions can increase Black 
unemployment by almost $14 \%$, and reduce visible export earnings by a quarter ${ }^{15}$. Their study also estimates that South African GDP would be reduced by $7 \%$ and domestic use of resources by about $11 \%$. The South African Embassy in the U.S. projects that divestment policies have resulted in the loss of 800000 jobs totally, that supported 4 million workers and their families. Banning the import of agricultural commodities alone (including lobster fishing) will result in 446000 jobs lost that support 2 million workers; and restrictions on the import of South African coal will cost 75000 Black jobs, while the textile ban and iron and steel ban could result in 153000 jobs being löst. ${ }^{16}$ It is clear, therefore, that sanctions have had an effect on employment, but that effect has been disproportionately felt in the economy. More Blacks have lost, and will lose, jobs than Whites. A clear estimate of the impact of sanctions on the socioeconomic state of Blacks is still not available. However, the overwhelming anecdotal evidence is sufficient to convince anybody that it is hurting the Blacks far more than it is hurting the Whites.

\section{Black reaction to sanctions}

How do Blacks respond to divestment and sanctions? The evidence here also is mixed. Support for sanctions among South Africa's Blacks was never as universally popular as the pro sanctions lobby believed. Public opinion surveys conducted last July by Mark Orkin in association with the Capetown based Institute for Black Research, ${ }^{17}$ found that $1 / 4$ of Blacks supported sanctions even at the cost of many jobs, but an overwhelming 48\% opposed sanctions if it meant the loss of many jobs. The special commission appointed by the South African Catholic Bishops Conference concluded that "it seems logical that black people desperately want to end the oppression of apartheid, and are willing to endure some hardship to see this happen. It seems, however, that if the policy is likely to produce a loss of their vitally needed jobs, most Blacks prove tentative about pressing the issue". ${ }^{18}$ The Commission concludes "it cannot be said that Blacks favor sanctions and are prepared to endure the hardship, a view apparently held by a minority only. For when the stark reality of loss of jobs is presented, then quite humanly, this spectre forces the preference for sanctions into the background". 19

Chief Minister Buthelezi, a leader of 6.7 million Zulus, notes that "divestment is a recipe for disaster. Our need is for peaceful change and foreign investment creates jobs which bring money to Blacks. Money means power. Blacks cannot really achieve their political rights on empty stomachs, without a roof over their heads". ${ }^{20}$ In addition, Chief Ministers Sskosana (Kwandikde), E. J. Mabuza (Kangwane), C. N. Phatide (Suthos), T. K. Mopeli (Suthos), Lennox Sebe (Xhosas), Patrick Mphepho (Vendas), and George Matanzima (Xhosas), all tribal chiefs who are heads of state in various Black homelands, all are opposed to sanctions. Together these chiefs represent nearly 17 million Blacks. Buthelezi, in a statement on March $11,1987^{21}$ went on to say that Black workers were politically doped into supporting a strategy they barely understood. He blames Dr. Allan Boesak, Archbishop Tutu, and Chris Dlamini for much of the problem. Chief Buthelezi has persistently opposed economic pressure against South Africa.

Reverend Allan Boesak has been a proponent of sanctions, as well as Archbishop Tutu. However, after the GM withdrawal, even Rev. Allan Boesak has been having mixed feelings. He clarified his stand further when he indicated that sanctions and divestment were part of a total package that they called for, and not just an isolated strategy. ${ }^{22}$ In fact, he notes that divestment is fairly low on the priority list. What Boesak and Tutu advocate is sanctions that could hit hard at the South African government, things that could be felt immediately, such that the government would have no choice but to capitulate. If that can be accomplished, Rev. Boesak claims that Blacks will be able to sustain the hardship that is required. Denis Huxley, the Catholic Archbishop of Durban, predicts that sanctions and divestments, and the resulting hardships faced by Blacks would precipitate conflicts that could go on for twenty years, and end in total devastation of the country. Other opinion leaders tend to support this view. Alan Paton, the author of the internationally acclaimed book Cry the Beloved Country, also indicates that sanctions, if they have the effect of putting a man out of work, is disastrous.

Chris Dlamini, a vice president of one of South Africa's more radical trade unions, supports sanctions in principle, but is totally 
opposed to disinvestment He advocates that the disinvestment oriented organizations should discuss with Black labor a way to arrive at a solution that will help the Blacks, rather than disinvesting to satisfy public opinion in their own countries. Interviews with numerous Black workers also indicate their disillusionment with sanctions. Goodwill Mpizi, a Black worker in the Eastern Cape Province seaport of East London, who has been out of a job for ten months, indicates that the mood of the people is changing. "Many of us are hungry, and we hurt when we see our families not eating. People are beginning to steal from each other and fight each other instead of fighting the government"23. An additional factor contributing to the ill effects of sanctions is the fact that South Africa's economy was hurt by a four year recession even before the anti-apartheid sanctions campaign began.

Consequently, in a nutshell, the real trouble with sanctions as a political weapon is that it hurts the Blacks more than the Whites.

\section{The effect of sanctions on the economy}

According to Standard Bank's and Liberty Life's latest economic, reviews, there is a gradual economic recovery in South Africa in 1987. The Liberty review believes that a $3 \%$ growth in Gross Domestic Product is attainable. Supporting this view is an expected moderate rise in private consumption expenditure due to: (a) higher projected revenue from gold and other metals; (b) improved agricultural crop sales; (c) Civil servant pay increases; and (d) fiscal stimulus possibly from a reduction in taxes. The Standard Review also cited as encouraging, the consistent upward movement of exports, retail sales and manufacturing production, good rains, and a healthier gold price and exchange rate, in recent months. A caveat about inflation was also issued. Activity in the foreign exchange market has contributed to a stronger rand. There was almost a $40 \%$ increase in diamond sales in 1986 over 1985 , and the central selling organization says this increase results from the continued strong demand for both rough and polished stones, in the second case, particularly for larger quality gems. ${ }^{24}$

The above paragraph was put together from various news reports during January 1987 in South Africa. As is evident, no talk about the effects of economic sanctions is mentioned. This description implies that economic sanctions have had practically no effect in general on the South African economy. However, considering the extensive news coverage given to the imposition of economic sanctions and divestment by various organizations, we would expect the South African economy to be reeling under an economic disaster. What are some of the reasons why sanctions do not appear to have had any effect? This section seeks to explore those reasons.

First, disinvestment has made South African corporations, organizations and managers richer. This has happened because foreign corporations have had to sell their organizations, frequently to incumbent managers, but more often to South African conglomerates, at very low prices. For example, Anglo American Corporation, one of South Africa's 5 large conglomerates that dominate the South African economy, acquired South Africa's largest bank, Barclay’s National, from its British parent organization. Anglo paid about \$8.06 for stock trading at $\$ 10.30$. Through this purchase South Africa will save more than 30 million Rand (\$14 million) in foreign dividend payments annually. Divestment has also been a boon to the South African Government

Industrial Complex. Allied Techonics Corp (AL- TRON) acquired ITT (SA) from the U.S. company. In addition, in the last few years, it has also acquired a string of other foreign organizations' subsidiaries, from the U.S., Britain, France and Holland, including Motorola and Asea. Such activity has increased the economic strength and power of local White owned corporations. In addition, when freed from foreign ownership they gain the ability to bid on defense and government contracts and can also cut out the costly social responsibility programs implemented by foreign owners in conformity with Sullivan and other principles. Five large White owned conglomerates control most of the economic activity in South Africa, and these are the organizations that have grown fastest consequent to divestments.

Second, and by far the most important reason why sanctions cannot have any major effect, is due to South Africa's sophisticated industrial base and vast mineral resources. Almost $60 \%$ of its export earnings are from low volume, high value, difficult to sanction items like precious metals, diamonds, and strategic minerals. In addition, South Africa is one of the most self sufficient economies in the world. It can generate almost all its annual capital needs internally, and it actually sustained a net outflow of long term capital 
after 1976 until the government imposed a debt moratorium in mid-1985. If sanctions are having any effect at all it is in that it is forcing South Africa to reorient itself towards increased import substitution. If necessary, at a price, South Africa has the technical capacity to build anything. They are reasonably self-sufficient in oil through oil from coal plants that provide $70 \%$ of their liquid fuel needs. They also produce their own armaments, and actually export arms to 23 countries.

South African businesses are easily exporting all kinds of sanctionable goods to all parts of the world. Despite sanctions, Far Eastern markets and the Soviet Bloc are expected to remain accessible. Coal exports remain steady at about 40 million tons despite decreased demand due to the French and Danish embargoes. Steel is also increasingly exported to the Far East Besides, Africa itself is a large customer for South African products. South Africa's tremendous mineral wealth ensures that it has many products that the world sorely needs, (see Table IV).

The rising price of gold is rejuvenating the South African economy. ${ }^{25}$ The economy, it is said, lives and dies by the price of gold. However, the demand for gold is a relatively stable phenomenon. Economists figure for every $\$ 10$ increase in the price of an ounce of gold, South Africa rakes in another \$200 million in annual export earnings. During April 1987 gold had risen from about $\$ 405$ an ounce to $\$ 445.50$ an ounce. This implies that within a month projected 1987 South African export earnings have increased by $\$ 800$ million. For a country facing tight credit restrictions from its international lenden, and various economic sanctions, this is quite a luxury.

TABLE IV

South Africa's mineral reserves

\begin{tabular}{lll}
\hline Mineral & $\begin{array}{l}\text { Western world } \\
\text { rank }\end{array}$ & $\begin{array}{l}\text { Percentage of } \\
\text { world resources }\end{array}$ \\
\hline Manganese & 1 & $93 \%$ \\
Chromium & 1 & $84 \%$ \\
Platinum & 1 & $83 \%$ \\
Gold & 1 & $63 \%$ \\
Vanadium & 1 & $61 \%$ \\
Alumino Silicates & 1 & $47 \%$ \\
Fluorspar & 1 & $46 \%$ \\
Cobalt & 1 & $43 \%$ \\
Diamonds & 2 & $29 \%$ \\
Vermiculite & 2 & $29 \%$ \\
Coal & 2 & $18 \%$ \\
Antimony & 2 & $17 \%$ \\
Uranium & 2 & $17 \%$ \\
\hline
\end{tabular}

- South Africa has $11 \%$ of the world reserves, but transports $32 \%$ of the world reserves from Zambia and Zaire. Source: 1985, South African Yearbook. U.S. Deparament of Commerce, 1985-1986.

A report published by the U.S. Geological Survey highlights South Africa's global dominance as a source of platinum group metals. According to forecasts made, there will be an upsurge in the demand for platinum in Europe, for use in devices for cutting lead in petrol as anti-pollution measures from the next year. The fuel emission standards of the U.S. have spread to Europe, and worldwide consumption of platinum is expected to increase. The study highlighted the extent of the world's reliance on the platinum group metals, i.e. platinum, palladium, rhodium, ruthenium, iridium and osmium. South Africa has $72 \%$ of the world's known and 
economically mineable platinum with the Soviet

Union having $26 \%$. The balance $2 \%$ is shared between the U.S. and Canada (see Tables V and VI).

Consequently, South Africa has a position of leverage in the world's mineral markets that makes it extremely difficult for most countries to cut off all des with South Africa. Gold and other precious metals bring in about $75 \%$ of South Africa's foreign exchange earnings and contribute $20 \%$ to its Gross Domestic Product Gold, therefore, and platinum are unlikely targets of sanctions. The mineral dependence of the U.S. on South Africa is considerable. As a result, these minerals become unsanctionable items (see Table VII). While Congress has imposed sanctions against the purchase of uranium from South Africa, it has not imposed any sanctions on the purchase of the "big five"; chromium, manganese, platinum, vanadium and cobalt.

A total trade boycott of all South African business could cost South Africa \$2.5 billion in foreign exchange and eliminate 300 000 White jobs. Despite all the bans against purchases of South African uranium, the U.S. still processes South African uranium, if only for non U.S. customers. When there is a need, a way will be found, and that's why economic sanctions will not have the desired effect.

In addition, South Africa also obtains considerable leverage by means of its strategic location. Located on the vital Cape of Good Hope sea lane, South Africa holds one of the most tactical geographical locations in the world. Control of the Cape yields enormous advantages in peace and in war. South Africa also possesses the most modem, best equipped strategic ports and harbors in the entire African continent. Combined with its location and mineral wealth, South Africa represents the most important Southern Hemisphere ally to the western world. This becomes another reason why the U.S. has to be careful about alienating South Africa. A teaming up of the Soviet Union and South Africa

TABLE V

South Africa - ranking in mineral exports

World rank

Minerals

in exports

(1) Vermiculite, Gold, Vanadium Manganese, Andalusites, Sillimanites, Terro Chromium, Terro Manganese, Antimony Inoxide, Manganese Ore, Chromium Ore

(2) Platinum Group Metals, Diamonds, Fluorspar, Antimony Concentrates, Uranium and Zirconium

2

(3) Asbestos, Coal 3

(4) Titanium 4

(5) Iron Ore, Silver 7

(6) Lead 8

(7) Copper, Phosphates 9

(8) Tin Nickel 10

Nickel 12

TABLE VI

Mineral reserves combined South Africa and U.S.S.R

\begin{tabular}{llll}
\hline & $\begin{array}{l}\text { \% Republic of } \\
\text { South Africa }\end{array}$ & \% U.S.S.R & \% Combined \\
\hline Platinum & $79 \%$ & $20 \%$ & $99 \%$ \\
Manganese & $71 \%$ & $21 \%$ & $92 \%$ \\
Chromium & $78 \%$ & $12 \%$ & $90 \%$ \\
Vanadium & $20 \%$ & $60 \%$ & $80 \%$ \\
Gold & $59 \%$ & $16 \%$ & $75 \%$ \\
Fluorspar & $46 \%$ & $4 \%$ & $50 \%$ \\
Cobalt & $43 \%$ & $3 \%$ & $46 \%$ \\
Uranium & $17 \%$ & $13 \%$ & $30 \%$ \\
\hline
\end{tabular}

Source: U.S. Department of Mines, U.S. Department of Commerce, 1985-1986 South African Yearbook 1985.

could potentially shut down the entire western world in about six months, according to Rep. David Mamot (R- VT). ${ }^{26}$ The recent instability of the Suez Canal due to unrest in the Middle East has increased the importance of the Cape sea route. By that route comes $80 \%$ of European NATO's oil consumption, $80 \%$ of its strategic minerals and $25 \%$ of its food requirements.

These factors, therefore, raise no surprise why sanctions are ineffective. The imposition of sanctions could have several other effects also on the political processes. Experts estimate that the increased isolation of South Africa from the rest of the world will force 
TABLE VII

Mineral dependence of U.S.A on South Africa

\begin{tabular}{lrr}
\hline Mineral & $\begin{array}{l}\text { \%US. import } \\
\text { dependence }\end{array}$ & $\begin{array}{l}\text { \% Supplied by } \\
\text { South Africa }\end{array}$ \\
\hline Chromium & $100 \%$ & $56 \%$ \\
Ferrochromium & $98 \%$ & $44 \%$ \\
Diamonds & $100 \%$ & $67 \%$ \\
Gold & $71 \%$ & $13 \%$ \\
Fluorspar & $83 \%$ & $29 \%$ \\
Ilmenite & $75 \%$ & $7 \%$ \\
Manganese & $99 \%$ & $33 \%$ \\
Ferromanganese & $75 \%$ & $43 \%$ \\
Platinum Metals & $84 \%$ & $67 \%$ \\
Vanadium & $52 \%$ & $52 \%$ \\
Uranium & $30 \%$ & $24 \%$ \\
Cobalt & $95 \%$ & $61 \%$ \\
\hline
\end{tabular}

\section{Source: South African Yearbook, ITA, U.S. Department of Commerce, 1985-1986.}

the Whites more to the right, and increase their resistance to attempts to eradicate apartheid. In addition, these sanctions are forcing South Africa to become increasingly self sufficient. The more it does so, the less is the ability of foreign governments to pressure the South African government With fewer foreign firms and fewer capital imports, the South African economy will grow more slowly than otherwise, and that is the extent to which current sanctions may effect The Forbes report ${ }^{27}$ estimates that instead of growing at the rate of $5 \%$ to $6 \%$ a year, it will grow at the rate of $3 \%$ a year. But the fact remains that the economy will still grow.

Consequently, sanctions do not solve the problem of acting as an economic force to bring about political change. It has not had any success in bringing about any major economic impact on the economy. In the final analysis, it has hurt Blacks more than Whites. Having already imposed the sanctions, divested or disinvested, the U.S. no longer has much influence in South Africa.

\section{The effects of sanctions on Southern Africa}

The imposition of sanctions on South Africa has also one major and very unpleasant side effect and that is die impact on the economies of the countries in Southern Africa.

This is largely because the countries of Southern Africa are dependent on South Africa in numerous ways. The main countries concerned are Botswana, Lesotho, Malawi, Swaziland, Zaire, Zambia and Zimbabwe. All these countries are heavily reliant on South Africa to maintain their import and export trade. Lesotho, for example, is completely surrounded by South African territory and totally dependent on South African rail and road transportation. Zambia and Zimbabwe are also dependent to a large extent on South African transportation facilities to conduct trade of their goods. If international sanctions result in South Africa closing its borders, the effect on these neighboring countries could be disastrous. Factories, mines and commercial farms would progressively shut down. People would become unemployed. The tax base would shrink, and inflation would soar. President Queff Masire of Botswana pointed out that $90 \%$ of Botswana's imports and exports are channelled through South Africa. Zambia, Zimbabwe and Zaire are heavily reliant on South Africa's road and rail transport systems and its ports (all these are landlocked countries). (See Table VIII.) 
TABLE VIII

Proportions of foreign trade traffic of Southern African

states routed through the Republic of South Africa

\begin{tabular}{lll}
\hline Country & \% Imports & \% Exports \\
\hline Zaire & $57 \%$ & $45 \%$ \\
Zambia & $70 \%$ & $40 \%$ \\
Malawi & $60 \%$ & $50 \%$ \\
Zimbabwe & $68 \%$ & $65 \%$ \\
\hline
\end{tabular}

Another significant form of dependency is in employment Mr. Shirley Abbot, U.S. ambassador to Lesotho, $\operatorname{cites}^{28}$ that more than one million Black Africans from neighboring countries earn their living from South Africa. Their wages are crucial to the economies of these neighboring nations. Sanctions would send all these workers back to their countries, resulting in increased unemployment and consequent social instability. See Table IX for registered foreign workers in South Africa. As many or more workers work there illegally.

TABLE DX

Registered foreign workers in South Africa June 30, 1985

\begin{tabular}{lrrr}
\hline Country & \multicolumn{1}{c}{ Male } & Female & \multicolumn{1}{c}{ Total } \\
\hline Angola & 39 & 5 & 44 \\
Botswana & 26411 & 1403 & 27814 \\
Lesotho & 136291 & 3536 & 139827 \\
Malawi & 29486 & 658 & 30144 \\
Mozambique & 68614 & 51 & 68665 \\
Swaziland & 20567 & 1688 & 22255 \\
Zambia & 823 & 10 & 833 \\
Zimbabwe & 7411 & 17 & 7428 \\
Other & 73310 & 688 & 73998 \\
$\quad$ Total & 362952 & 8056 & 371008 \\
Bopothatzwana & 191835 & 83650 & 275485 \\
Ciskei & 55924 & 9499 & 65423 \\
Transkei & 342056 & 30071 & 372127 \\
Venda & 50676 & 7686 & 58362 \\
$\quad$ Grand total & 1003443 & 138962 & 1142405 \\
\hline
\end{tabular}

Source: Southern Africa Fact Sheet, Southern African Editorial Services, P.O. Box 781303, Sandton, South Africa.

For every wage earning job in Lesotho, six jobs in South Africa are filled by workers from Lesotho and the corresponding ratio for Botswana is 3:2 and for Swaziland 2:1. In 1984 Black miners working in South Africa took home to neighboring countries more than $\$ 400$ million in remittances and deferred pay $^{29}$. This is only from Black miners, and represents a substantial injection of revenues into the economies of these developing countries. Further injections come from the contributions from the Customs Union with South 
Africa. (70\% of Lesotho's government revenue is from this source.) Many plants and factories in these neighboring countries sell goods only to South Africa. It is to be borne in mind that $12 \%$ of Mozambique's GNP is earned by Mocambicans working in South African gold mines. Consequently it is clear that in deciding about sanctions against South Africa, countries must also assess the impact on Southern Africa.

When talking about sanctions, it may be pertinent to remember the lesson of Rhodesia (now Zimbabwe). International sanctions were enforced against Rhodesia between 1965 and 1980. Despite these sanctions, Rhodesia was known to have traded with as many

\section{TABLE X}

Total repatriated earnings by foreign workers in registered
employment in Republic of South Africa

\begin{tabular}{lcc}
\hline Country & 1980 & 1983 \\
& R. million & R. million \\
\hline Angola & 0.1 & 0.1 \\
Botswana & 32.0 & 47.6 \\
Lesotho & 153.3 & 280.6 \\
Malawi & 30.7 & 51.3 \\
Mozambique & 66.6 & 116.8 \\
Swaziland & 13.2 & 32.1 \\
Zambia & 0.6 & 1.0 \\
Zimbabwe & 15.4 & 8.7 \\
Other* & 3.5 & 139.68 \\
$\quad$ Total & 315.4 & 677.8 \\
\hline
\end{tabular}

\section{- Other includes Southwest Africa and Namibia.} Source: South African Consulate General, Chicago.

as 60 countries. Sanctions led to the development in Rhodesia of a more dynamic business community, a greater diversification in agriculture, the development of import substituting industries and a steady rise in the living standards of the white community without a corresponding increase in living standard of the Blacks. Rhodesia's natural resources were miniscule compared to those of South Africa. Their transport and communication network had hardly developed. The sanctions and the lesson of Rhodesia is relevant to the South African situation today. Against that background, the effect of the imposition of international sanctions against South Africa will be disastrous for the countries of Southern Africa and at best will have only a marginal impact on South Africa itself

\section{Conclusion}

When one looks at U.S. involvement in South Africa, two factors emerge rather clearly. One is that the Sullivan Principles, although deemed to be ineffective in dismantling apartheid, did have some positive impact on the economic and social status of Blacks. Total withdrawal, on the other hand, has had a disastrous impact on the Blacks, in terms of reductions in Black employment, and social welfare programs in the areas of education, welfare, health and training. Furthermore, the imposition of economic sanctions and disinvestment has, if anything, only strengthened the economic power of the Whites, and perhaps increased their determination to keep apartheid.

In view of this, it would seem that any change in apartheid must come from within South Africa itself. Indications are that the 
process has already begun in South Africa. The dramatic announcement by the leaders of the Dutch Reformed Church (which provides the religious ideology to bind the system together), that its policy of desegregation was a mistake, is liable to hasten the process of change considerably. Consequently, U.S. policy on South Africa needs to be reconsidered, and reoriented in terms of how the U.S. can make contributions to hasten the process of change. It may well mean, that a continued presence in South Africa may be the better answer.

\section{Notes}

1. The Wall Street Journal, 5/29/87, p. 19.

2. Eric E. Wiggin, 'American Companies: A Force in Ending Apartheid?', Family Protection Scoreboard, Special Edition on South Africa, 1987 edition, p. 18.

3. Ibid., p. 19.

4. The Wall Street Journal, $11 / 6 / 86$, p. 36.

5. The Wall Street Journal, $2 / 11 / 87$.

6. David Romano, 'The Divestment Rush', Family Protection Scoreborad, Special 1987 edition on South Africa.

7. ILO Committee on Action Against South Africa, 1986, ILO Publications.

8. The Wall Street Journal, 11/25/86, p. 32.

9. The Wall Street Journal, 12/3/86.

10. Ibid.

11. Ibid.

12. Op. cit., Eric Wiggin.

13. Op. cit., Wall Street Journal, 12/3/86.

14. The Washington Times, 11/17/86.

15. The Wall Street Journal, 11/25/86.

16. Gene Vosseler, 'Consequences of Sanctions and Disinvestment', Special 1987 edition on South Africa, Family Protection Scoreborad, 1987.

17. The Wall Street Journal, $2 / 11 / 87$.

18. Ibid.

19. Ibid.

20. 2" Business and Society Review, Spring, 86, No. 57.

21. Op. eit

22. 22 Transcript of Interview with Allan Boesak, March 25, 1987, PB.S. Network, MacNeil/Lehrer News Hour.

23. $25 \mathrm{lbid}$.

24. The Wall Street Journal.

25. The Wall Street Journal. 4/23/87.

26. David, Romano, 'Strategic Importance of South Africa', Special Edition on South Africa, Family Protection Scoreboard.

27. Forbes Magazine, 'Economic Sanctions Are Not Working', Report from South Africa, 3/9/87.

28. South African Facts Sheet, March 1986. South African Editorial Services, (PTU) Ltd.

29. South African Embassy, Washington, D.C. 